\title{
Job Security, Satisfaction Influence Work Commitment
}

\author{
by Scott Reinardy
}

\section{A nationwide survey of newspaper journalists found that coping control, perceptions of job quality and job security and organizational commitment are significant, positive predictors of job satisfaction.}

$\mathbb{W}$

hen the aught decade began, there were about 56,400 newspaper journalism jobs. Following extensive buyouts, layoffs and cuts since 2008, that number had dwindled to about 41,500 - a 27 percent reduction in the newsroom workforce since 2001. ${ }^{1}$ Staffing in newsrooms hasn't been this low since the mid-1970s. ${ }^{2}$

As newsrooms slash their way to sustainability, what remains are "layoff survivors." The survivors are asked to do more with less, particularly in an online environment where readers demand immediacy and quantity. At the same time, the "survivors" contend with the anxiety that the other proverbial layoff shoe could drop at any time.

Early research examining layoffs concentrated on the unemployed. That changed in the mid-1980s with the Brockner studies. Brockner and his colleagues shifted the focus to examine the "survivors" of layoffs-employees who remain in an organization following personnel reductions. "Survivor syndrome" is generally defined as the emotional and behavioral attributes of those who remain with an organization following job reductions. ${ }^{4}$

The purpose of this study was to examine the self-affirmation of newspaper newsroom layoff survivors and their job security, job quality, job satisfaction, organizational commitment and coping strategies. In the context of layoffs, Steele's self-affirmation theory ${ }^{5}$ suggests that layoffs per se might not be the

Reinardy is an associate professor in the William Allen White School of Journalism and Mass Communications at the University of Kansas. 
instigator of employees' negative reactions. ${ }^{6}$ Researchers suggest survivors' self-integrity is the lynchpin to self-affirmation and comprised of self-esteem (viewing oneself as good), self-identity (viewing oneself as rational) and having control to determine outcomes. ${ }^{7}$ All aspects of self-integrity are affected by the negativity created by the stressors (e.g., job insecurity or unfairness) ${ }^{8}$ that follow a layoff.

Previous research has demonstrated that organizational downsizing is associated with declines in job satisfaction, ${ }^{9}$ reduced job performance and a reduction in job security. ${ }^{10}$ If employees are not satisfied in their jobs and fear being laid off, reduced work quantity and quality is inevitable. Also, new job responsibilities, as well as the threat of additional layoffs, create uncertainty among employees who begin to question their value to the organization and their value to the work itself. ${ }^{11}$

Survey data will assist in examining the current condition of layoff survivors in newspaper newsrooms. More newspaper layoffs appear imminent; understanding the dynamic of remaining newsroom personnel is instrumental to the future of specific newspapers and perhaps the future of newspaper journalism. Previous research has shown that stress and anxiety of layoff survivors increase as workers demonstrate guilt, anger, fear and relief. ${ }^{12} \mathrm{How}$ that translates in the newsroom over time might have a lasting impact on the newspaper and its remaining employees. New roles and responsibilities create an uncertain environment for layoff survivors. Perceptions of job security, job quality, job satisfaction, as well as how survivors cope with the changes, will influence commitment to the organization and perceptions of self worth and integrity in the workplace.

\section{Literature Review}

Multiple layoffs in an organization naturally create anxiety and uncertainty among remaining employees. "Job security" becomes a vague notion when colleagues have inexplicably disappeared. Job insecurity can be the impetus for issues such as anxiety, stress, financial concern and organizational change. ${ }^{13}$ Greenhalgh and Rosenblatt ${ }^{14}$ said the sense of powerlessness is compounded by layoff survivors' experiences of cuts and the threat of additional cuts. The authors write:

The sense of powerlessness arises because the employee does not know what corrective action to take to avert the perceived threat. ${ }^{15}$

Greenhalgh and Rosenblatt ${ }^{16}$ said job insecurity is exacerbated when the overall job market for a particular skill declines. That is certainly true for those in newspapers where recent layoffs have flooded the market with thousands of journalists. As newspapers shift to online delivery that includes streaming 
video and blogging, the traditional skills-reporting and writing the story for the morning paper-appear to be in lesser demand. For layoff survivors in staff-depleted newsrooms, the workload has increased, and the time to report and write has been condensed.

Layoffs, particularly multiple layoffs, challenge an employee's commitment to an organization. Through psychological identification, individuals develop attachments to organizations that create a bond..$^{17}$ The individual and organization share similar attitudes, values and goals that become a part of an individual's cognitive response. ${ }^{18}$ In developing a means to measure organizational commitment, $\mathrm{O}^{\prime}$ Reilly and Chatman ${ }^{19}$ examined compliance (behaviors adopted to gain rewards), identification (individual pride in organizational membership) and internalization (shared values between the individual and the organization). Organizational identification and internalization are strongly linked to pro-social behaviors and negatively tied to turnover.

There are several challenges in retaining organizational commitment, particularly during cutbacks. Job loss for journalists is just one aspect of job insecurity, particularly for those who consider it more than just a job. Petzall, Parker and Stoeberl write:

Job insecurity is the perception of the potential loss of continuity in a job situation that can range from permanent loss of the job itself, to loss of valued job features. ${ }^{20}$

With the changing media landscape, a pink slip could signify being cut from a career. And what becomes of job value when skills acquired over a career are no longer adequate to fulfill the needs of the employer or consumer? Perhaps more to the point, what becomes of self-identity when the employment situation is volatile and the organization is laying off employees who appear to share the newspaper's values and goals?

Just as self-identity is an issue among journalists, so is job satisfaction, an area of research interest for nearly 50 years. While others dabbled in the area, sociologists Johnstone, Slawski and Bowman ${ }^{21}$ launched a new generation of research that examined the reasons behind satisfaction and journalists' commitment to the job. Of the more than 1,300 journalists in the Johnstone et al. study, about 83 percent said they expected to be working in the news media within five years, but about 25 percent of young journalists questioned their professional commitment.

What the Johnstone team started, Weaver and Wilhoit continued with three subsequent studies during the course of nearly 30 years. Job satisfaction during that time fluctuated greatly. The Johnstone et al. study reported that about 48 percent of journalists said they were "very satisfied" in their work. By the 2002 Weaver et al. study, that number had dipped to 33 percent. $^{22}$ In nearly all of the Weaver and Wilhoit work, job satisfaction was contingent upon autonomy in the job, the esteem of the organization and the perception of how well the 
organization informed the public. ${ }^{23}$ Also, similar to the Johnstone et al. study, by 2002 about 17 percent of journalists said they intended to leave the job within five years and cited job security, stress and an unfavorable work environment, such as deadlines and hours. ${ }^{24}$ Other studies have demonstrated correlations between job satisfaction and work overload, ${ }^{25}$ organizational support ${ }^{26}$ and commitment to produce quality journalism. ${ }^{27}$

Several of those issues have come to the forefront the past few years. Watching colleagues leave, assuming more job responsibilities and working in fear of additional layoffs amplify what is already a stressful occupation. Journalists expect a certain amount of stress and even thrive under the daily pressures of deadlines, managerial demands and competition. Selye ${ }^{28}$ considered by some to be the father of modern stress research, said stress is part of the normal "wear and tear" on the body. ${ }^{29} \mathrm{He}$ said some degree of stress at all times is warranted, and stress isn't necessarily bad. Selye also said each person manages stress differently; what overwhelms one person might be exhilarating to another.

The implications of stress hinge on how well people cope with it. Coping plays a role during specific stressful situations, such as a looming deadline or a confrontational boss. ${ }^{30}$ Lazarus and Folkman ${ }^{31}$ defined coping as

... constantly changing cognitive and behavioral efforts to manage specific external and/or internal demands that are appraised as taxing or exceeding the resources of the person. ${ }^{32}$

Building upon the principles of Folkman and Lazarus, among others, Latack ${ }^{33}$ conceptualized coping into two categories-control (pro-active, take charge approach) and escape (avoid the issues). Latack reported that during more stressful times brought on by role uncertainty, control strategies are less prevalent. ${ }^{34}$

Following a series of personnel cuts, uncertainties about the job and job responsibilities may be at peak levels. The threat of additional cuts may create an environment that alters work expectations. If someone has done a good job and still gets laid off, job expectations appear unpredictable. Survivors may implement either control or escape coping strategies in an effort to proactively save their jobs or avoid thinking about additional job cuts. Either way, uncertainty about job responsibilities, and perhaps even organizational goals, may shift.

Armstrong-Stassen ${ }^{35}$ tested the coping concepts of Lazarus and Folkman with 200 technicians of a telecommunications company. She reported that control coping was positively correlated with organizational commitment and job performance, but the workers had less intent of leaving the company. ${ }^{36}$

Coping strategies are integral when contending with job survival. ArmstrongStassen ${ }^{37}$ studied how managers who survived downsizing reacted in terms of job satisfaction, job performance and job insecurity. In the two-year study, she determined while managers showed no significant change in job satisfac- 
tion, there was a decline in job performance. After job performance dropped, it stabilized at the lower level.

Steele ${ }^{38}$ analyzed the cognitive coping process as it relates to self-regard, and the rationalization system that allows for individuals to "explain ourselves and the world at large, to ourselves." ${ }^{39}$ The function of the constant self-explanation system is to maintain a "phenomenal experience" of self conceptions and images, which includes affirmation that we are "competent, good, coherent, unitary, stable, capable of free choice, capable of controlling important outcomes and so on." 40 Steele writes:

\section{I view these self-affirmation processes as being activated by information that threat- ens the perceived adequacy or integrity of the self and as running their course until this perception is restored, through explanation, rationalization and/or action. ${ }^{41}$}

When a concept is inconsistent or conflicts with a perception of self-identity, the individual will attempt to affirm his or her selfidentity with countermeasures. For instance, although smokers are generally aware that smoking is associated with serious health ailments, they continue to smoke. Steele contends that the smoker is not required to rationalize his or her smoking habit but can engage in some other unrelated smoking activity in an effort to verify his or her self-identity. The smoker might volunteer to do charity work or spend more time with his children in a larger effort to support the notion that he is a good person. While the harms of smoking do not disappear, the smoker's resilience through affirmation poses a lesser threat to the larger context of self-identity.

Additionally, Steele ${ }^{42}$ expanded his analysis to examine how individuals dealt with the implications a threat might have on self-regard. In addition to the physical threats related to smoking, there's a perceived threat to self-integrity and "one's sense of adaptive and moral adequacy." ${ }^{43}$ Others' judgment of the 
smoker might create a threat to his self-integrity, and he needs to discover ways to cope with that.

Threats can come in terms of life-threatening situations to those who challenge self-integrity. While a tornado might create a physical threat, it probably creates minimal threat to self-regard. However, a job review may create a threat to self-regard but poses little physical threat. Adapting to one threat can allow the adaptation of the other. If the smoker chooses to quit smoking, he preserves his health and his self-regard. ${ }^{44}$

Using Steele's self-affirmation theory, Wiesenfeld, Brockner, Petzall, Wolf and Bailey ${ }^{45}$ examined self-identity as employees coped with layoffs and the job insecurity that followed. Their contention was that layoff survivors' job insecurity was a direct threat to self. Individuals create identity through their work and their organization. When layoffs occur and the employee makeup of the organization shifts, survivors' perceptions of the organization also shift. ${ }^{46}$

Newspaper newsroom layoff survivors are coping with job insecurity, job satisfaction, commitment to the organization and the quality of their work. For many, journalism is not just a job or career, but a calling that is deeply entwined with self-integrity. ${ }^{47}$

The current state of newspaper newsrooms is challenging the long-held identities of the layoff survivors. Newsroom colleagues are gone and job demands have changed with online obligations. In addition, journalism is being conducted under the threat of more layoffs. How these stressors are affecting identity and the affirmation of that identity will be examined in this study.

\section{Hypotheses and Research Questions} potheses:

Building on previous research, this study will address the following hy-

H1:

Control coping and job quality will be positive predictors of job satisfaction among newspaper newsroom layoff survivors.

Latack's coping strategies outline how employees contend with work complications by either taking control of the situation or avoiding the issues altogether. Layoff survivors face new work challenges, lost relationships and the threat of additional cuts. The uncertainty might possibly chip away at an employee's self-identity and self-esteem. Individually, work provides explanation as to who we are and how we fit into a larger society. ${ }^{48}$ Changes in work environment force us to adapt. Those who aggressively adapt and adjust to changes will surely have higher levels of job satisfaction.

Additionally, Hackman and Oldham ${ }^{49}$ contend that work effectiveness hinges on work quantity and quality. Work quality motives workers and improves performance. Hackman and Oldham write, "Performing well, for most people, 
means producing high-quality work of which one can be proud." ${ }^{50}$ Because work is an extension of self, high-quality work affirms an individual's internal perception as a good employee who is respected. Hackman and Oldham examined the internal and external perceptions of job quality. They recognized that while internal perceptions were important, affirmation from work colleagues was also important to individual satisfaction.

Examining layoff survivors' coping skills combined with their perception of job quality will lend insight into workers' adaptability and internal perception of the job. Combining the two variables will assist in constructing a more comprehensive view of job satisfaction.

\section{H2:}

An increase in organizational commitment of newsroom layoff survivors will result in higher levels of job satisfaction.

Over time, workers and organizations develop shared attitudes, goals, values and traits that become inherent to a worker's cognitive response, particularly during times of transition. ${ }^{51}$ The shared traits establish identification with the organization and what it represents, which in turn creates organizational commitment. When the organization suffers, so does the individual. Through the organization, self-integrity is represented in a larger, external context. Maintaining high levels of commitment in the organization affirms a belief in self as well.

\section{H3:}

Journalists intending to leave their newspaper will be more likely than those intending to stay to have lower levels of job satisfaction, organizational commitment, control coping, job security and perceptions of job quality.

For an individual, self-affirmation is demonstrated in the work being conducted by the worker and the work produced by the organization. ${ }^{52}$ If a journalist is no longer committed to the work and intends to leave the job, it's only logical that the organizational social structure is collapsing for that individual. There is fear of job loss and a diminished perception of job quality. When the perception of the organization backslides, so does the perception of self. When job dissatisfaction takes hold, and workers no longer effectively cope with organizational change, the only real alternative is to leave the job.

Toexamine these issues, the study included the following research questions:

\section{RQ1:}

How do journalists' perceptions of job quality, job security, organizational commitment and coping strategies affect their job satisfaction?

\section{RQ2:}

Are journalists who are committed to a career in newspapers more committed to the job, more satisfied and have higher perceptions of job quality than those not intent on staying in newspapers? 


\section{Method}

A 75-question survey was constructed utilizing previously established measurements of job security, job quality, job satisfaction and coping. The first section of the four-section survey included questions about job security, followed by a section inquiring about job quality and satisfaction. Section three asked about coping strategies and included some additional questions about work habits, career choice and change of career if they were laid off. The final section requested demographic information.

A list of daily newspapers was collected from the "Papercuts" website dedicated to tracking newspaper cuts. ${ }^{53}$ Newspapers that experienced cuts from Jan. 1, 2008, through May 31, 2009, were included in this study. A database of email addresses of newsroom workers was established by individually checking each newspaper's website. The list of e-mails included news clerks, reporters, news editors, copy editors, photographers, graphic designers, online reporters, online editors, columnists, managing editors and executive editors.

The 139 newspapers included in the database represented all geographic regions of the United States and all circulation sizes from less than 5,000 to more than 1 million. E-mails of 9,629 journalists were collected. In July 2009, journalists received an e-mail invitation to participate in the survey. The e-mail explained the purpose of the study and included a SurveyMonkey link to the questionnaire. Journalists were invited to participate on a voluntary basis and assured that their responses would be confidential. A reminder e-mail wa sent in August 2009. The survey remained available for one month.

\section{Measurements}

\section{Job Security}

The instrument was developed by Caplan, Cobb, French, Harrison and Pinneau ${ }^{54}$ and included four questions asking about job security $(1=$ somewhat certain; $5=$ very certain). Cronbach's alpha was .68 .

\section{Organizational Commitment}

In this study, O'Reilly and Chatman's commitment scale included four items from the "identification" scale and three items from the "compliance" area. A seven-point Likert-like scale ( $1=$ strongly disagree; $7=$ strongly agree) was included. Cronbach's alpha for commitment identification (.81) was acceptable but commitment compliance (.05) was not, so it was not used in this study.

\section{Overall Job Satisfaction}

Cammann, Fichman, Jenkins and Klesh's ${ }^{55}$ Michigan Organizational Assessment Questionnaire included a subcategory to measure job satisfaction (1 $=$ strongly disagree; $7=$ strongly agree). Cronbach's alpha was .88 . 


\section{Coping}

A modified version of Latack's $\mathrm{s}^{56}$ coping scales was used in this study, which included two areas: control coping (eight questions) and escape coping (six questions). The original measurement had a total of 28 items $(1=$ hardly ever do this; 5 = almost always do this). The Cronbach's alpha for control coping was .80 in this study, but the alpha for escape coping was .48, so it was not used.

\section{Job Quality}

For this study, Hackman and Oldham' $\mathrm{s}^{57}$ five-item perceived job quality scale was used. The questions asked about autonomy in the job, variety, importance, and feedback received from managers and fellow employees ( 1 = very little; 7 $=$ very much). Cronbach's alpha was .71 .

\section{Findings}

Of the 9,629 e-mails sent to newspaper journalists, 539 were "undeliverable," reducing the sample size to 9,090. Of those, 2,159 participants completed the survey for a response rate of about 24 percent, which is comparable to other online surveys..$^{58}$ More to the point, the number of participants in this study exceeds similar newspaper journalism studies, including the work of Weaver and Wilhoit, which traditionally feature about 1,000 journalists. ${ }^{59}$ Mean substitution replaced missing values in this dataset but no more than 5 percent of any variable was replaced.

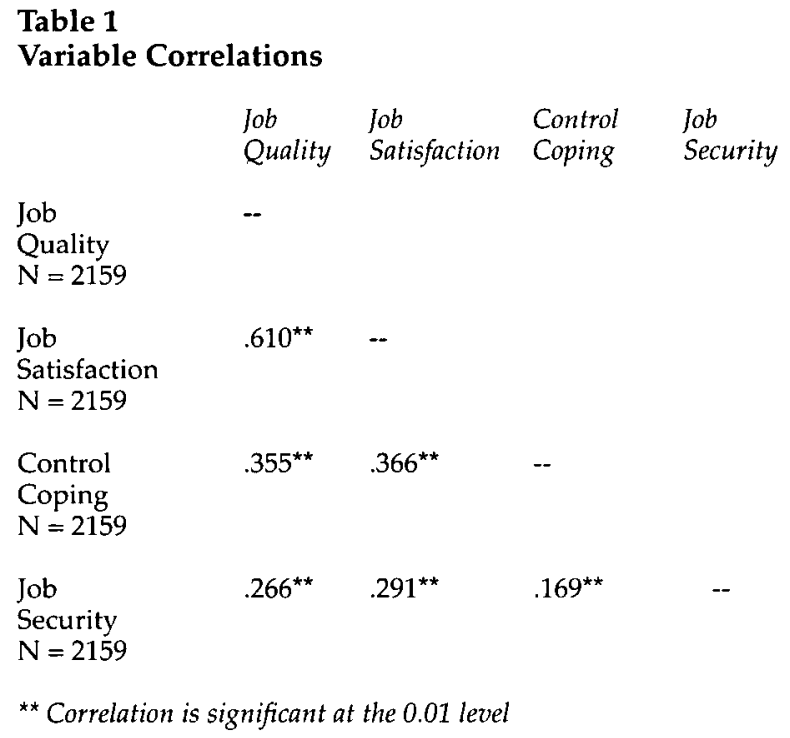


The average age of the respondents was 44 with 20 years of professional experience, including 13 years at their current newspaper. The average circulation of the newspapers was about 244,000 , which included 132 different circulations and at least 62 different newspaper ownership groups or independent families. The participants average about 44 hours of work per week. About 61 percent were male and 89 percent were Caucasian. Reporters made up the largest group (40.3 percent), followed by managers (13.6 percent), news editors ( 13.4 percent), copy editors ( 9.6 percent) and photographers ( 7.3 percent).

\section{RQ1 [see Table 1] asked about the perception among newsroom layoff survivors of job quality, job security and organizational commitment and the effects on job satisfaction.}

Control coping had a small, positive and significant correlation to job satisfaction (.37), job quality (.36) and job security (.27). Job security also had a small, positive and significant correlation to job satisfaction (.29) and job quality (.27), as job satisfaction had a moderate, positive and significant correlation

\begin{tabular}{|c|c|c|c|}
\hline & $\begin{array}{l}\text { Yes, intending } \\
\text { to retire } \\
\text { in newospapers } \\
(418)\end{array}$ & $\begin{array}{l}\text { No, not intending } \\
\text { to retire } \\
\text { in newospapers } \\
\text { (710) }\end{array}$ & $\begin{array}{l}\text { Don't } \\
\text { know } \\
(784)\end{array}$ \\
\hline Job Satisfaction & 17.4 & 13.1 & $16.0^{*}$ \\
\hline $\begin{array}{l}\text { Organizational } \\
\text { Commitment }\end{array}$ & 21.6 & 18.3 & $20.7^{\star}$ \\
\hline Job Quality & 26.1 & 22.9 & $25.2^{\star}$ \\
\hline
\end{tabular}

\section{Table 3}

Multiple Linear Regression Predicting Overall Job Satisfaction Through Control Coping and Job Quality

\begin{tabular}{|c|c|c|c|c|c|}
\hline \multirow[b]{2}{*}{ Model } & \multicolumn{2}{|c|}{$\begin{array}{l}\text { Unstandardized } \\
\text { Coefficients }\end{array}$} & \multicolumn{2}{|c|}{$\begin{array}{l}\text { Standardized } \\
\text { Coefficients }\end{array}$} & \multirow[b]{2}{*}{ Sig. } \\
\hline & $B$ & Std. & $\begin{array}{l}\text { Beta } \\
\text { Error }\end{array}$ & $t$ & \\
\hline (Constant) & -.468 & .531 & & -.882 & .378 \\
\hline Control Coping & .146 & .016 & .174 & 8.920 & .000 \\
\hline Job Quality & .453 & .016 & .543 & 27.865 & .000 \\
\hline
\end{tabular}


to job quality (.61). Because of the inadequate alpha, escape coping was not examined in this study.

\section{RQ2 asked if journalists who are committed to a career in newspapers are more committed to the job, more satisfied and have higher perceptions of job quality than those not intent on staying in newspapers?}

The survey question allowed a "yes," "no," or "don't know" answer to the question, "Do you believe you will continue to work in newspaper journalism until retirement?" An independent sample t-test indicated that compared to those not expecting to retire from newspaper work $(n=710)$, journalists intending to remain in newspapers $(n=418)$ had significantly higher rates of organizational commitment, job satisfaction and perception of job quality. The largest differences were with job satisfaction (mean difference $=4.38$ ) and commitment (mean difference $=4.30$ ). Not surprisingly, journalists who answered "don't know" $(n=785)$ fell in the middle. On the three variables, they had significantly higher levels than those who said "no" and significantly lower rates than those who said "yes." Although significant, the mean difference between the "don't know" group and the "yes" group was much smaller when compared to the "no" group. [See Table 2]

Multiple linear regression analysis was used to examine the first hypothesis. $\mathrm{H} 1$ stated that control coping and job quality will be positive predictors of job satisfaction among newspaper newsroom layoff survivors. When job satisfaction was the dependent variable, control coping and job quality accounted for about 39 percent of the variance (adjusted $\mathbf{r}$-square $=39.1$ ). Control coping and job quality were positive, significant predictors of job satisfaction. [See Table 3] Therefore, H1 was supported.

\section{A linear regression was used to examine $\mathrm{H2}$, which said an increase in organiza- tional commitment of newsroom layoff survivors, will result in higher levels of job satisfaction.}

Because organizational commitment identification had an adequate reliability coefficient and commitment compliance did not, commitment identifi-

\begin{tabular}{|c|c|c|c|c|c|}
\hline \multirow[b]{2}{*}{ Model } & \multicolumn{3}{|c|}{$\begin{array}{l}\text { Unstandardized } \\
\text { Coefficients }\end{array}$} & \multicolumn{2}{|c|}{$\begin{array}{l}\text { Standardized } \\
\text { Coefficients }\end{array}$} \\
\hline & $B$ & $\begin{array}{l}\text { Std. } \\
\text { Error }\end{array}$ & Beta & $t$ & Sig. \\
\hline $\begin{array}{l}\text { 1. (Constant) } \\
\text { Commitment ID }\end{array}$ & $\begin{array}{l}3.796 \\
.483\end{array}$ & $\begin{array}{l}.349 \\
015\end{array}$ & 586 & $\begin{array}{l}10.868 \\
32614\end{array}$ & .000 \\
\hline
\end{tabular}




\begin{tabular}{|c|c|c|}
\hline & $\begin{array}{l}\text { Intending } \\
\text { to leave } \\
(n=449)\end{array}$ & $\begin{array}{l}\text { Not intending } \\
\text { to leave } \\
(n=864)\end{array}$ \\
\hline Job Satisfaction & 11.7 & $17.3^{\star \star}$ \\
\hline $\begin{array}{l}\text { Commitment } \\
\text { Identification }\end{array}$ & 17.1 & $21.6^{\star \star}$ \\
\hline Control Coping & 29.3 & $32.3^{* *}$ \\
\hline Job Security & 11.0 & $12.7^{\star \star}$ \\
\hline Job Quality & 21.9 & $26.0^{\star *}$ \\
\hline
\end{tabular}

cation was only used in this model. When job satisfaction was the dependent variable, commitment identification accounted for about 34 percent of the variance (adjusted $r$-square $=34.3$ ). Commitment identification was a positive and significant predictor of job satisfaction [see Table 4], so H2 was supported.

H3 said journalists intending to leave their newspaper will have lower levels of job satisfaction, organizational commitment, control coping, job security and perception of job quality than will those intending to stay.

In answering the question, "Do you have any intention of leaving newspaper journalism," 23 percent $(n=449)$ answered "yes," 44 percent $(n=864)$ answered "no," and 33 percent answered "don't know." A t-test determined that those intending to leave newspapers had significantly lower levels of job satisfaction, organizational commitment, control coping, job security and perception of job quality. In fact, compared to those who answered "don't know," those intending to leave journalism had significantly lower levels on all the variables as well. Except for job security, the "yes" respondents had significantly higher levels on all the variables than did those who answered "don't know." [See Table 5] H3 was supported.

\section{Conclusions}

The purpose of this study was to examine the self-affirmation of newspaper newsroom layoff survivors and their job security, job quality, job satisfaction, organizational commitment and coping strategies. For an individual, Steele's 
self-affirmation is demonstrated in the work being conducted by the worker and the work produced by the organization. ${ }^{60} \mathrm{New}$ roles and responsibilities create an uncertain environment. Perceptions of job security, job quality, job satisfaction, as well as how survivors cope with the changes, influence commitment to the organization and perceptions of self worth and integrity in the workplace.

In this study, coping control, perceptions of job quality and job security and organizational commitment were significant, positive predictors of job satisfaction. However, there were great distinctions among those intending to remain in newspaper journalism and those intending to leave. Job satisfaction, organizational commitment, control coping, job security and perception of job quality were significantly lower among journalists who intended to leave the profession.

Steele's ${ }^{61}$ self-affirmation theory suggests survivors' self-esteem, self-identity and personal control are affected by the negativity created by the stressors (e.g." job insecurity or unfairness) ${ }^{62}$ that follow a layoff. In threatening times, people are not only threatened in the physical sense (e.g., losing a job or career; salary reductions; new job responsibilities, etc.), but in the sense of self-identity. Because journalists deeply identify with their profession, ${ }^{63}$ the threat of being laid off not only from a job but possibly a career is a threat to self-integrity. Journalists in this study have demonstrated efforts to combat that threat. Self-esteem, in this case job satisfaction, is being bolstered by employees' commitment to their jobs, an aggressive, take-charge coping strategy and the perception that the job itself has merit. It certainly can be argued that these traits are indicative of those attempting to reaffirm their identity through countermeasures.

Wiesenfeld, et al. ${ }^{64}$ acknowledged that individuals create identity through their work and their organization. When layoffs occur and the employee makeup of the organization shifts, survivors' perceptions of the organization also shift. The shift can be a threat to "individuals' sense of self-esteem, self-identity or personal control." ${ }^{15}$ For some journalists in this study, the threat appears to have met some resistance. For others, the threat is quite real. The distinctions are apparent when comparing the journalists who intend to remain in the profession and those intending to leave. The "leavers" are struggling with the aspects that create self-affirmation, but that is to be expected. After watching their colleagues lose their jobs, the layoff survivors have been given new, different and more work responsibilities in an environment that has dramatically changed. Many are in an unfamiliar world of technology being asked to do work that is foreign to them (blog, tweet, shoot video, etc.). In a profession characterized as a calling, it's no surprise that self-esteem, self-identity and personal control is waning. The very definition of who they are as journalists and how long they will be allowed to continue practicing their profession in a traditional, familiar fashion is uncertain. It is not uncommon for layoff survivors to question their value to the organization and their value to the work itself. ${ }^{66}$

There are limitations to this study, including the sample. This is not a universal sample of layoff survivors, so some opinions may have been excluded. 
Also, there is no way of determining if a disproportionate number of disgruntled newspaper journalists completed the survey. Also, although the survey was sent through e-mail, there is no way to determine exactly who completed the survey.

Despite the limitations, more than 2,000 newspaper journalists participated in this study. The results provide a unique examination of how layoff survivors are contending with the newsroom transformation. Understanding the perspective of remaining journalists can assist in developing managerial strategies to bolster self-affirmation among newsroom employees. Addressing these issues becomes salient when layoff fears rise, job satisfaction dwindles and the quality and quantity of work diminishes. When these situations occur, newspapers won't need to initiate further layoffs; good journalists will choose to leave on their own.

\section{Notes}

1. Rick Edmonds, "TheState of the News Media 2010: An annual report on American journalism," http://stateofthemedia.org/2010/newspapers-summary-essay/news-investment/, (July 7, 2010).

2. The State of the News Media 2010, "Newspaper Newsroom Work Force," http://www. stateofthemedia.org $/ 2010 /$ chartland.php? $\mathrm{msg}=1 \& \mathrm{id}=1314 \& \mathrm{ct}=$ line\&dir $=\& \mathrm{sort}=\& \mathrm{c} 1=1 \& \mathrm{c} 2=1 \& \mathrm{c} 3$ $=0 \& c 4=0 \& c 5=0 \& c 6=0 \& c 7=0 \& c 8=0 \& c 9=0 \& c 10=0 \& d 3=0 \& d d 3=1,($ July 7,2010$)$.

3. Joel Brockner, Jeanette Davy and Carolyn Carter, "Layoffs, self-esteem and survivor guilt: motivational, affective and attitudinal consequences," Organizational Behaviour and Human Decision Processes, 16 (1985): 229-44; Joel Brockner, Jeff Grenberg, Audrey Brockner, Jenny Bortz, Jeanette Davy and Carolyn Carter, "Layoff equity theory and work motivation: further evidence for the impact of survivor guilt," Academy of Management Journal, 29 (1986): 373-84; Joel Brockner, Steven Grover, Thomas Reed, Rocki Lee DeWitt and Michael O'Malley, "Survivors reactions to layoffs: we get by with a little help from our friends," Administrative Science Quarterly, 32 (1987): 526-41; Joel Brockner, "The effects of work layoffs on survivors," California Management Review, 34 (1988): 9-28; Joel Brockner, Rocki Lee DeWitt, Steven Grover and Thomas Reed, "When it is especially important to explain why: factors affecting the relationship between managers' explanations of a layoff and survivors' reactions to the layoff," Journal of Experimental Social Psychology, 26 (1990): 389-407.

4. Retha Wiesner, Leopold Vermeulen and Craig Littler, "Survivor syndrome: effects on middle managers in South Africa," SAJEMS NS, 2 (1999): 390-406.

5. Claude Steele, "The psychology of self-affirmation: sustaining the integrity of the self," in Advances in Experimental Psychology, 21, (ed.) Leonard Berkowitz (San Diego, CA: Academic Press, Inc., 1988): 261-302.

6. Marjorie Armstrong-Stassen, "Coping with transition: a study of layoff survivors," Journal of Organizational Behavior, 15 (1994): 597-621; Joel Brockner and Batia Wiesenfeld, "Living on the edge (of social and organizational psychology): the effects of job layoffs on those who remain," in Social Psychology in Organizations: Advances in Theory and Research, (eds.) J. Keith Murnighan (Englewood Cliffs, NJ: Prentice-Hall, 1993): 119-40.

7. Batia Wiesenfeld, Joel Brockner, Barbara Petzall, Richard Wolf and James Bailey, "Stress and coping among layoff survivors: a self-affirmation analysis," Anxiety, Stress and Coping, 14 (2001): 15-34.

8. Armstrong-Stassen, "Coping with transition;" Brockner and Wiesenfeld, "Living on the edge of social and organizational psychology;" Wiesenfeld et al., "Stress and coping among layoff survivors."

9. Wang-Bae Kim, "Economic crisis, downsizing and "layoff survivor's syndrome," Journal of Contemporary Asia, 33 (2003): 449-64; Wiesner et al., "Survivor Syndrome," 390-406; Marjorie 
Armstrong-Stassen, Sheila Cameron and Martha Horsburgh, "The impact of organizational downsizing on the job satisfaction of nurses," Canadian Journal of Nursing Administration, 9(1996): 8-32.

10. Kim, "Economic crisis, downsizing and "layoff survivor's syndrome," 449-64; Weisner et al., "Survivor syndrome," 390-406; Kim Cameron, Sarah Freeman and Aneil Mishra, "Organizational downsizing," in Organizational Changeand Redesign: Ideas and Insights for Improving Performance, (eds.) George Huber and William Glick (New York: Oxford University Press, 1993): 19-65.

11. Steele, "The psychology of self-affirmation."

12. Leonard Greenhalgh and Zehava Rosenblatt, "Job insecurity: toward conceptual clarity," Academy of Management Review, 9 (1984): 438-48; Susan Holm and Jane Hovland, "Waiting for the other shoe to drop: help for the job-insecure employee," Journal of Employment Counseling, 36 (1999): 156-66; Barbara Petzall, Gerald Parker and Philipp Stoeberl, "Another side to downsizing survivors' behavior and self-affirmation," Journal of Business and Psychology, 14 (2000): 593-603; Wiesenfeld, et al. "Stress and coping among layoff survivors."

13. Greenhalgh et al., "Job insecurity: toward conceptual clarity," 438-48; Susan Ashford, Cynthia Lee and Philip Bobko, "Content, causes and consequences of job insecurity: a theory-based measure and substantive test," Academy of Management Journal, 32 (1989): 803-829; Karl Kuhnert, Ronald Sims and Mary Lahey, "The relationship between job security and employee health," Group and Organization Studies, 14 (1989): 399-410; Holm et al., "Waiting for the other shoe to drop," 156-66.

14. Greenhalgh et al., "Job insecurity: toward conceptual clarity," 438-48.

15. Greenhalgh et al., "Job insecurity: toward conceptual clarity," 442.

16. Greenhalgh et al., "Job insecurity: toward conceptual clarity," 438-48.

17. Charles O'Reilly III and Jennifer Chatman, "Organizational commitment and psychological attachment: the effects of compliance, identification and internalization on prosocial behavior," Journal of Applied Psychology, 71 (1986): 492-99.

18. Jerome Kagan, "The concept of identification," Psychological Review, 65 (1958): 296-305.

19. O'Reilly and Chatman, "Organizational commitment and psychological attachment," 492-99.

20. Petzall et al., "Another side to downsizing survivors' behavior," 595.

21. John W.C. Johnstone, Edward J. Slawski and William W. Bowman, The News People: A Sociological Portrait of American Journalists and Their Work (Chicago, IL: University of Illinois Press, 1976).

22. David Weaver, Randal Beam, Bonnie Brownlee, Paul Voakes and G. Cleveland Wilhoit, The American Journalist in the 21st Century: U.S. News People at the Dawn of a New Millennium (Mahwah, NJ: Lawrence Erlbaum Associates, 2007).

23. Weaver et al., The American Journalist in the 21st Century; David H. Weaver and G. Cleveland Wilhoit, The American Journalist: APortrait of U.S. News Peopleand Their Work, (Bloomington, IN: Indiana University Press, 1986); David H. Weaver and G. Cleveland Wilhoit, The American Journalist in the 1990s: U.S. News People at the End of an Era (Mahwah, NJ: Lawrence Erlbaum Associates, Inc., 1996).

24. Weaver et al., The American Journalist in the 21st Century.

25. Scott Reinardy, "Satisfaction vs. Sacrifice: Sports Editors Assess the Influences of Life Issues on Job Satisfaction," Journalism \& Mass Communications Quarterly, 84 (2007): 105-121; Marie Hardin and Stacie Shain, "Strength in Numbers? The Experiences and Attitudes of Women in Sports Media Careers," Journalism \& Mass Communications Quarterly, 82 (2005): 804-819.

26. Reinardy, "Satisfaction vs. Sacrifice."

27. George L. Daniels and C. Ann Hollifield, "Times of Turmoil: Short- and Long-Term Effects of Organizational Change on Newsroom Employees," Journalism \& Mass Communications Quarterly, 79 (2002): 661-680.

28. Hans Selye, The Stress of Life (NY: McGraw-Hill Book Company, 1956).

29. Selye, The Stress of Life, 3.

30. Susan Folkman and Richard Lazarus, "An analysis of coping in a middle-aged community sample," Journal of Health and Social Behavior, 21 (1980): 219-39.

31. Richard S. Lazarus and Susan Folkman, Stress, Appraisal and Coping (New York: Springer Publishing Company, 1984). 
32. Lazarus and Folkman, Stress, Appraisal and Coping, 141.

33. Janina Latack, "Coping with job stress: measures and future directions for scaledevelopment," Journal of Applied Psychology, 71 (1986): 377-85.

34. Latack, "Coping with job stress."

35. Armstrong-Stassen, "Coping with transition," 597-621.

36. Armstrong-Stassen, "Coping with transition," 597-621.

37. Marjorie Armstrong-Stassen, "Downsizing the federal government: a longitudinal study of managers' reactions," Canadian Journal of Administrative Sciences, 15 (1998): 310-321.

38. Steele, "The psychology of self-affirmation."

39. Steele, "The psychology of self-affirmation," 262.

40. Steele, "The psychology of self-affirmation," 262.

41. Steele, "The psychology of self-affirmation," 262.

42. Steele, "The psychology of self-affirmation," 261-302.

43. Steele, "The psychology of self-affirmation," 263.

44. Steele, "The psychology of self-affirmation," 261-302.

45. Wiesenfeld et al., "Stress and coping among layoff survivors," 15-34.

46. Wiesenfeld et al., "Stress and coping among layoff survivors."

47. Howard Gardner, Mihaly Csikszentmihalyi and William Damon, Good Work: When Excellence and Ethics Meet (NY: Basic Books, 2001) 163-164.

48. Steele, "The psychology of self-affirmation."

49. Richard Hackman and Greg Oldham, Work Redesign (Philippines: Addison-Wesley Publishing Co., 1980).

50. Hackman and Oldham, Work redesign, 91.

51. O'Reilly and Chatman, "Organizational commitment and psychological attachment."

52. Steele, "The psychology of self-affirmation;" O'Reilly and Chatman, "Organizational commitment and psychological attachment."

53. Erica Smith, "Papercuts: Newspaper buyouts and layoffs," http://graphicdesignr.net/ papercuts/, (June 1, 2009).

54. Robert Caplan, Sidney Cobb, John R.P. French, Jr., R. Van Harrison and Samuel R. Pinneau, Jr., Job Demands and Worker Health: Main Effects and Occupational Differences (Ann Arbor, MI: University of Michigan, 1975).

55. Cortlandt Cammann, Mark Fichman, Douglas Jenkins and John Klesh, "Assessing the attitudes and perceptions of organizational members," in Assessing Organizational Change: A Guide to Methods, Measures, Practices, eds. Emanuel Seashore, Edward Lawler III, Philip Mirvis and Cortlandt Cammann (NY: John Wiley, 1983).

56. Latack, "Coping with job stress," 377-85.

57. Hackman and Oldham, Work Redesign, 91.

58. Scott Reinardy, "The Maslach burnout inventory measures burnout of sports journalists," Journalism \& Mass Communication Quarterly, 83 (2006): 397-412; Asch as cited in Mathias Schonlau, Ronald Fricker Jr. and Marc Elliott, Conducting Research Survey via E-Mail and the Web (Santa Monica, CA: Rand, 2002).

59. Weaver et al., The American Journalist in the 21st Century; David H. Weaver and G. Cleveland Wilhoit, The American Journalist: A Portrait of U.S. News Peopleand Their Work, (Bloomington, IN: Indiana University Press, 1986); David H. Weaver and G. Cleveland Wilhoit, The American Journalist in the 1990s: U.S. News People at the End of an Era (Mahwah, NJ: Lawrence Erlbaum Associates, Inc., 1996).

60. Steele, "The psychology of self-affirmation;" O'Reilly and Chatman, "Organizational commitment and psychological attachment."

61. Steele, "The psychology of self-affirmation," 261-302.

62. Armstrong-Stassen et al., "Coping with transition," 597-621; Brockner et al., "Living on the edge," 119-40.

63. Gardner et al., Good Work. 
64. Wiesenfeld et al., "Stress and coping among layoff survivors," 15-34. 65. Wiesenfeld et al., "Stress and coping among layoff survivors," 31. 66. Steele, "The psychology of self-affirmation." 
Copyright of Newspaper Research Journal is the property of Newspaper Research Journal and its content may not be copied or emailed to multiple sites or posted to a listserv without the copyright holder's express written permission. However, users may print, download, or email articles for individual use. 